Кравцов С.С., к. держ. упр. Київський національний торговельно-економічний університет, м. Київ, Україна https://scholar.google.com.ua/citations?user=y-tBSegAAAAJ\&hl=ru

\title{
БЕЗБАР'СРНИЙ ТУРИЗМ В УКРАЇНІ: ШЛЯХИ ВИРІШЕННЯ ПРОБЛЕМ
}

В Україні станом на 1 січня 2015 р. загальна чисельність людей 3 інвалідністю (без урахування тимчасово окупованих територій Криму та м. Севастополя) становила 2568532 особи (або 5,98\% у загальній структурі постійного населення країни [1]. Хоча це $\epsilon$ свідченням величезного потенційного ринку для подорожей та туризму, він все ще залишається значною мірою недостатньо розвинутим, оскільки наявна проблема недоступності туристичних об'єктів та послуг, а також в певній мірі дискримінаційна політика відносно цієї категорії споживачів туристичних послуг.

Метою наукової роботи - визначення проблем розвитку безбар'єрного туризму в Україні та шляхи їх вирішення

Доступність має бути забезпечена по всьому ланцюжку туристичних послуг, зв'язки між туристичними об'єктами, послугами i розвагами повинні бути добре вивірені і злагоджені. Елементами ланцюжка туристичних послуг є система управління в сфері туризму; інформація для туристів і реклама (інформування, бронювання); міське середовище і архітектура; транспорт і транспортні термінали; проживання, харчування; культурні об'єкти (музеї, театри, кінотеатри, і ін.).В Україні не створено дієвого механізму державної підтримки безбар'єрного туризму й в основному його розвиток проявляється в локальних ініціативах, і трактується як туризм для осіб $з$ обмеженими можливостями, а саме осіб 3 інвалідністю (в основному обмежується «візочниками»). Організацією безбар'єрного туризму в Україні займаються різні інституції - реабілітаційні установи, громадські та церковні організації, бюро подорожей, навчальні заклади. Серед громадських організацій (ГО), які надають інформацію щодо організації туризму для неповносправних осіб в Україні - ГО «Зелений хрест» (м. Львів), ГО інвалідів зору «Дивосвіт» (м. Ужгород), ГО «МАРТ» (м. Чернівці), ГО інвалідів «СЛІД», ГО людей з обмеженими можливостями «День» та ін. Але, 
як виявив аналіз цього питання, зазначені організації не мають широкої реклами, та лише деякі з них мають власні веб-сайти та, на жаль, навіть на цих сайтах бракує інформації про доступні тури, подорожі, екскурсї̈ та інші послуги.

В табл. 1 наведено запропоновані напрями вирішення проблем розвитку безбар'єрного туризму.

Таблицяя 1

\section{Напрями вирішення проблем розвитку безбар'єрного туризму}

\begin{tabular}{|c|c|}
\hline Рівні здійснення & Конкретні дії \\
\hline $\begin{array}{l}\text { Держава та } \\
\text { місцеві органи } \\
\text { влади }\end{array}$ & $\begin{array}{l}\text { 1. Розроблення власних державних веб-сайтів відповідно до } \\
\text { міжнародних стандартів доступності (стандарт WAI, мета якого - } \\
\text { зробити вміст інтернету доступним всім користувачам, в тому } \\
\text { числі користувачам з обмеженими можливостями). } \\
\text { 2. Створення Програми розвитку безбар'єрного туризму в Україні, } \\
\text { а також створення нормативно-правової бази щодо унормування } \\
\text { певних вимог до безбар'єрного простору, регулювання та } \\
\text { контролю за їх виконанням. } \\
\text { 3. Часткове фінансування подорожей для людей з обмеженими } \\
\text { фізичними можливостями, а також імплементація міжнародних } \\
\text { стандартів. } \\
\text { 4. Видання та поширення рекомендацій щодо облаштування } \\
\text { об’єктів туристичної інфраструктури з дотриманням вимог. }\end{array}$ \\
\hline $\begin{array}{l}\text { Туроператори } \\
\text { та туристичні } \\
\text { агентства }\end{array}$ & $\begin{array}{l}\text { 1. Розроблення унікальних маршрутів, дозвіллєвих та анімаційних } \\
\text { програм та заходів для людей з обмеженими можливостями. } \\
\text { 2. Консультація людей з обмеженими життєвими можливостями } \\
\text { щодо доступних міст, культурних об'єктів, транспорту, готелів і т. д. } \\
\text { 3. Надання доступної, вивіреної, чіткої інформації щодо доступних } \\
\text { об’єктів інфраструктури та культурних об’єктів. }\end{array}$ \\
\hline $\begin{array}{l}\text { Громадські } \\
\text { організації }\end{array}$ & $\begin{array}{l}\text { 1. Створення пошукової системи, яка пропонує доступний засіб } \\
\text { бронювання готелів, спеціально розроблений для забезпечення } \\
\text { повного самодостатнього онлайн-бронювання для людей } 3 \\
\text { візуальною, моторною, чуттєвою та інтелектуальною недостатністю. } \\
\text { 2. Професійна орієнтація людей з обмеженнями по здоров’ю, шляхом } \\
\text { проведення екскурсій до музеїв середніх і вищих навчальних } \\
\text { закладів. } \\
\text { 3. Створення карт доступності місць для інвалідів-візочників. }\end{array}$ \\
\hline $\begin{array}{l}\text { Постачальники } \\
\text { послуг }\end{array}$ & $\begin{array}{l}\text { 1. Впровадження політики надання послуг за принципом } \\
\text { справедливості (недискримінаційній основі). } \\
\text { 2. Забезпечення безпечної, зручної та економічної транспортної та } \\
\text { іншої інфраструктури, пов'язаної з туризмом. }\end{array}$ \\
\hline
\end{tabular}

Таким чином, широкий спектр проблем розвитку безбар'єрного туризму свідчить про необхідність посиленої уваги з боку держави й суспільства. Націлившись в діяльності на дану категорію туристів туроператори отримають можливість обслуговувати великий і все більш зростаючий ринок. 
1. Інформація щодо чисельності осіб з інвалідністю за даними 2011-2016 pр. [Електронний ресурс] : [Веб-сайт] // Фонд соціального захисту інвалідів. - Режим доступу : http://www.ispf.gov.ua/ShowPage. aspx?PageID=263 (дата звернення: 20.11.2018) 